\title{
Trichinella spiralis: nurse cell formation with emphasis on analogy to muscle cell repair Zhiliang $\mathrm{Wu}^{1}$, Lj Sofronic-Milosavljevic ${ }^{2}$, Isao Nagano ${ }^{1}$ and Yuzo Takahashi*1
}

Address: ${ }^{1}$ Department of Parasitology, Gifu University Graduate School of Medicine, Yanagido 1-1, Gifu, 501-1194, Japan and ${ }^{2}$ Institute for the Application of Nuclear Energy, Banatska 31b, 11080, Belgrade, Serbia and Montenegro

Email: Zhiliang Wu -wu@gifu-u.ac.jp; Lj Sofronic-Milosavljevic - sofronic@inep.cp.yu; Isao Nagano - isao@gifu-u.ac.jp;

Yuzo Takahashi* - yu3@gifu-u.ac.jp

* Corresponding author

Published: 19 August 2008

Parasites \& Vectors 2008, I:27 doi:10.1 I86/1756-3305-I-27
Received: 3 July 2008

Accepted: 19 August 2008

This article is available from: http://www.parasitesandvectors.com/content/I/I/27

(c) 2008 Wu et al; licensee BioMed Central Ltd.

This is an Open Access article distributed under the terms of the Creative Commons Attribution License (http://creativecommons.org/licenses/by/2.0), which permits unrestricted use, distribution, and reproduction in any medium, provided the original work is properly cited.

\begin{abstract}
Trichinella infection results in formation of a capsule in infected muscles. The capsule is a residence of the parasite which is composed of the nurse cell and fibrous wall. The process of nurse cell formation is complex and includes infected muscle cell response (de-differentiation, cell cycle reentry and arrest) and satellite cell responses (activation, proliferation and differentiation). Some events that occur during the nurse cell formation are analogous to those occurring during muscle cell regeneration/repair. This article reviews capsule formation with emphasis on this analogy.
\end{abstract}

\section{Introduction}

Parasites alter physiology and/or morphology of hosts in order to survive in a new environment. It is remarkable how some parasites make a new architecture in the host tissue, by morphological remodeling. Trichinella spiralis is a typical example. Parasites build their own home in the infected muscles. The home is a capsule which is composed of a collagenous wall and cellular components. The wall provides some protection to the parasite and the cellular component that takes care of the parasites in terms of metabolism. Because of its function, the name "nurse cell" has been given to the cellular components. Both the wall and nurse cell are of host, not parasite origin. Some parasitologists prefer the term nurse cell complex or capsule rather than the term cyst, because the term cyst is used for cells of parasite origin.

The capsule is prominent in the infected muscle; even an untrained pathologist will not overlook it during micro- scopic examination. The question that first comes to mind is how does Trichinella alter host cells and construct such unique place for living? Does Trichinella have some unknown specific tools?

This has been an enigma in spite of extensive studies. As early as 1966, Maier and Zaiman commented on the similarities between some of the changes which occur during nurse cell formation and those in muscle cell regeneration [1]. Steward and Read [2] presented a detailed comparison of ultrastructural and biochemical changes that occur during the two processes mentioned above and found them to be remarkably similar. They introduced the hypothesis that process of regeneration plays a significant role in the initial development of nurse cell. A series of recent studies provide more evidence to strengthen their ideas that Trichinella utilizes a repairing process of muscles cells to construct the capsule. In other words, after injury induced by parasite invasion, muscle cells start going 
through the process of repair, just like after any trauma. Trichinella borrows only the initial part of this repair process to construct its own home.

Despommier [3] has already elegantly reviewed the process of capsule formation with emphasis on nurse cell formation. The present review article deals with the whole process of capsule formation but puts more emphasis on the analogy between nurse cell formation and muscle cell repair.

\section{The analogy between nurse cell formation and muscle cell repair}

There are many similarities between the processes of nurse cell formation after Trichinella infection and regeneration of muscle cells after injury.

A skeletal muscle cell is susceptible to injury by direct trauma or indirect causes such as neurological dysfunction or innate genetic defects. Due to its remarkable ability of regeneration, an injured muscle cell initiates a finely orchestrated set of cellular responses, resulting in the regeneration of a well-innervated, fully vascularized and contractile muscle apparatus. The process of regeneration includes four stages, as reviewed by Wozniak et al. [4]: 1) satellite cell activation; 2) satellite cell proliferation; 3) differentiation and fusion; and 4) self-renewal of satellite cell.

Invasion by Trichinella new born larvae also causes muscle cell damage, which initiates the activation of satellite cells undergoing proliferation and re-differentiation $[5,6]$. In this case, the muscle cell affected by Trichinella infection initiates de-differentiation, cell cycle re-entry and arrest [7-11].

During this process, many events are similar in both nurse cell formation and muscle regeneration, for example, increase in the amount of sarcoplasmic matrix, the size and number of nuclei which migrate to the center of muscle fiber from the periphery, the size of affected myofibers, the number of mitochondria, DNA and RNA content, and increase in free ribosomes and intense proliferation of rough endoplasmic reticulum and smooth sarcoplasmic reticulum [2].

\section{Muscle development and regeneration: an overview}

A brief review on muscle genesis and regeneration process will provide basic information for understanding of the nurse cell formation process.

\section{Muscle genesis}

Skeletal muscles are derived from mesodermal precursor cells which originate from the somites. During embryonic development, mesodermal precursor cells are specific to myogenic lineage (known as myoblasts). Proliferating myoblasts withdraw from the cell cycle and terminally differentiate to myocytes. Finally, mononucleated myocytes specifically fuse to each other to form a multinucleated syncytium, which eventually matures into muscle fibers [12]. During the course of muscle development, a distinct subpopulation of myoblasts fails to differentiate, but remains associated with the surface of the developing myofiber as quiescent muscle satellite cells [13-15].

\section{Muscle repair}

The early events following muscle injury are muscle cell necrosis and accumulation of inflammatory cells within the damaged site, which is a process of degeneration. The activated mononuclear cells release factors that provide chemotactic signals to other inflammatory cells [16-18]. Neutrophils are first to come, followed by macrophages which phagocytose cellular debris and affect other aspects of muscle regeneration by activating myogenic cells [1921].

Following muscle degeneration, the repair process of muscle is activated. The activation and proliferation of satellite cells are important events necessary for muscle regeneration. The proliferation of satellite cells provides a sufficient source of new myonuclei for muscle repair. Satellite cells differentiate and fuse to each other or with existing damaged fibers for repair to form new myofibers $[4,22]$. The fundamental morphological characteristics are that newly formed myofibers have small caliber with centrally located myonuclei (Fig 1).

\section{Capsule formation}

Capsule formation (also known as cystogenesis) has been extensively studied by many authors. It involves complex steps and events which take place over a 20 day period from the time of initial larval invasion to the completion of the nurse cell [3].

Infection causes profound changes in host muscle cells, some of which are, in the beginning, similar with those involved in muscle regeneration. After new born larva invasion, dissolution and complete loss of myofibrillar organization occur [23]. A septum is formed to segregate the affected area (basophilic cytoplasm) from the intact area of the same muscle cell [5]. Infection causes the activation, proliferation and differentiation of satellite cells, which develop into eosinophilic cytoplasm [5,6].

Recent molecular biological studies have shown that many genes and signaling pathways are mobilized in nurse cell formation, for example, mitochondrial pathway mediated and death receptor pathway mediated apoptosis signaling, TGF- $\beta$ signaling pathway, as well as the genes related to cell differentiation, proliferation, cell cycle con- 

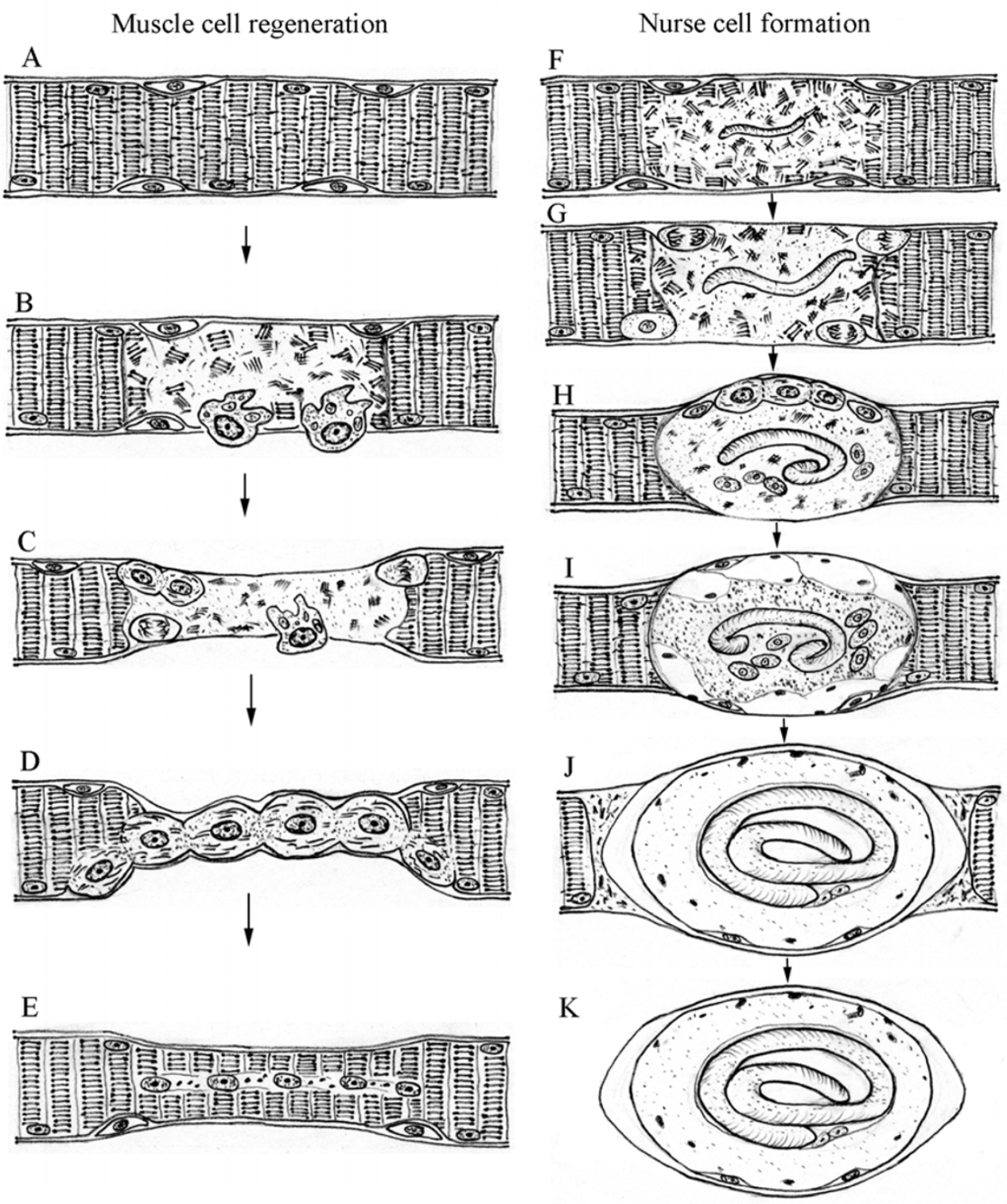

\section{Figure I}

Muscle cell regeneration: A: Normal muscle cell with myonuclei and satellite cells; B: Damaged muscle cell. Muscle injury causes inflammatory response and mononucleated cells are mobilized; C: Necrosis occurs in the damaged site. Macrophages invade the damaged tissue for cleaning up cellular debris. Satellite cells are activated; D: Activated satellite cells proliferate, differentiate and fuse to each other or with existing damaged muscle fibers; $\mathrm{E}$ : The regenerated new muscle cell in smaller caliber with centrally-located myonuclei and renewed satellite cells. The figure is modified from the textbook of MYOLOGY by Engel and Franzini-Armstrong. Nurse cell formation: F: Invasion of Trichinella larva causes dissolution and complete loss of myofibrillar organization; G: Satellite cells are activated. Basophilic transformation occurs in the infected muscle cell. A septum is formed to limit damaged area; $\mathrm{H}$ : Activated satellite cells proliferate, differentiate and fuse to each other or with the infected muscle cell, which provides eosinophilic cytoplasm. The infected muscle cell dedifferentiates, reenters cell cycle and arrests at G2/M. There are many hypertrophy nuclei; I and J: The eosinophilic cytoplasm (which is provided by satellite cells) increases in volume and the basophilic cytoplasm (which originates from infected muscle cell) decreases in volume; K: The mature nurse cell is formed. The cytoplasm of nurse cell is eosinophilic. 
trol, and apoptosis [6,9-11,24-27]. The terminally differentiated muscle cells re-enter the cell cycle and then arrest in apparent G2/M $[7,8,23]$. The developed nurse cell contains as many as 100 greatly enlarged nuclei with well developed nucleoli [28] and is surrounded by a collagenous capsule wall and circulatory rete $[29,30]$.

In the following paragraphs, each step of capsule formation is reviewed in detail in comparison with muscle cell regeneration.

\section{Dynamic changes in infected muscle cell cytoplasm}

The muscle cell will disintegrate if the damage is so extensive that cell can not be repaired, which is known as necrosis. This dead area is removed by scavenger cells such as macrophages through the phagocytosis process. When the damage is light, the muscle cell may undergo apoptosis or recover from the damage by repairing itself. In the case of Trichinella infection, the invasion itself does not seem to cause severe damage to the muscle cell. As such, the infected muscle cell does not undergo necrosis but it undergoes apoptosis instead. In the following paragraph, recent progress about the fate of infected and damaged muscle cells is discussed, because such information seems to be indispensable to better understand the process of nurse cell formation.

First of all, during the process of nurse cell formation, the existence of two kinds of cytoplasm within the nurse cell should be recognized, basophilic and eosinophilic cytoplasm [5]. Basophilic cytoplasm is formed by the transformation of the infected muscle cell after newborn-larva invasion ("basophilic transformation") [31,32]. The eosinophilic cytoplasm is derived from satellite cells and joins the nurse cell (This is discussed below). In the beginning of nurse cell formation, the basophilic cytoplasm is dominant, and as the nurse cell formation proceeds, the basophilic cytoplasm decreases in size and the eosinophilic cytoplasm increases in size with the ratio changing in a reciprocal manner. Consequently, the basophilic cytoplasm disappears from the nurse cell (Fig 1).

As for the basophilic cytoplasm, morphological and molecular biological data are available. The initial changes include disintegration of sarcomeres, lysis of myofilaments, increases in the amounts of rough and smooth endoplasmic reticulum, and hypertrophy of nuclei [31,32]. Morphological signs are identified as apoptosis $[5,24]$. There are irregular shaped nuclei with scattered and dense heterochromatin in basophilic cytoplasm. The mitochondria swelled and disappeared in the early phase of infection, and were replaced by new mitochondria that were smaller in size than those in normal muscle cells and had a hyper-density matrix, which was in good agreement with features of mitochondrial pyknosis in apoptosis $[33,34]$. TUNEL assay indicated that there was DNA fragmentation in some of the enlarged nuclei [27].

More light on the mechanisms of apoptosis in the basophilic cytoplasm has been thrown by molecular experiments, which showed that many apoptosis-related

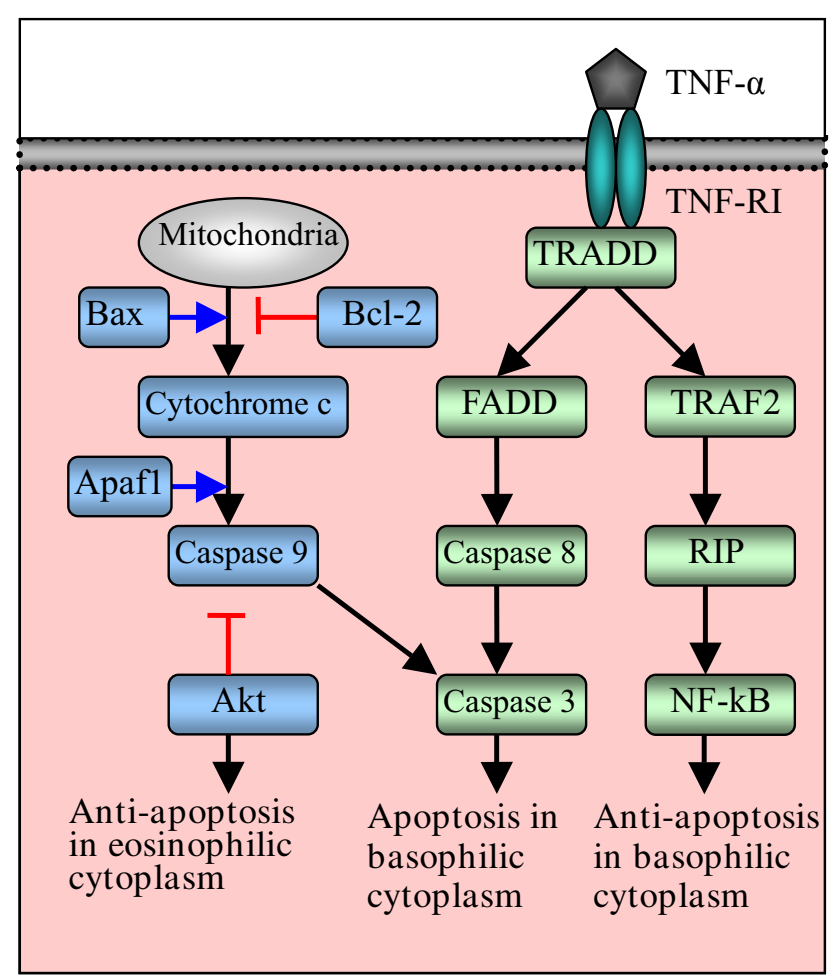

\section{Figure 2}

Schematic illustration of the involvement of death receptor pathway (right half) and mitochondrial pathway mediated (left half) apoptosis in nurse cell formation. Upon binding with TNF- $\alpha$, TNF-RI recruits TRADD which functions as a platform adapter that recruits several signaling molecules. The recruitment of TRADD and FADD results in autocatalytic activation of procaspase 8 . Activated caspase 8 cleaves effector procaspase 3 which plays a role in apoptosis in the basophilic cytoplasm of Trichinella infected muscle cells. On the other hand, the binding of TNF- $\alpha$ and TNF-RI induces the sequential recruitment of TRADD, TRAF2 and RIP, which leads to the activation of NF-kB. The activated NF-kB acts for anti-apoptosis in the basophilic cytoplasm. In mitochondrial pathway, Bax induces apoptosis by forming the membrane pore in mitochondria from which cytochrome $\mathrm{c}$ is released. Cytochrome c activates caspase 9 which in turn activates caspase 3 to induce apoptosis in infected muscle cells. As a co-factor, Apaf-I plays a role with caspase 9 in apoptosis in the basophilic cytoplasm. On the other hand, Akt plays an anti-apoptosis role in the eosinophilic cytoplasm by inactivating proapoptotic proteins such as Bad and caspase 9. This figure referred the review by Gupta [35]. 
genes were involved (Fig 2 and Table 1). There are two principal pathways for apoptosis initiation, the mitochondrial pathway and the death receptor pathway [35]. The up-regulated expressions of mitochondrial pathway mediated apoptosis factors (Bcl-2 associated protein $\mathrm{X}$ : BAX, Apoptotic protease activating factor 1: Apaf-1 and caspase 9) and death receptor pathway mediated apoptosis factors (tumor necrosis factor-alpha: TNF- $\alpha$, TNF receptor I, TNF receptor-associated death-damain: TRADD, caspase 8 and caspase 3) were observed in the basophilic cytoplasm of infected muscle cells, suggesting that both signaling pathways are activated in the cytoplasm (Fig 2) [24-27].

The fate of basophilic cytoplasm is thus clear; it disappears through the process of apoptosis in spite of the up-regulation of the genes for anti-apoptosis (TNF receptor associated factor 2: TRAF2, and receptor interactive protein: RIP). In fact, acid phosphatase activity was found to be high in basophilic cytoplasm, suggesting the presence of destructive processes [36]. On the other hand, the eosinophilic cytoplasm seems to tell a different story. This cytoplasm seems to be metabolically active, engaging in some metabolic transportation, because alkaline phosphatase activity, not acid phosphatase activity, was detected in the eosinophilic cytoplasm [36].
The eosinophilic cytoplasm is also exposed to stress from the parasite, and apoptosis genes are up-regulated. Interestingly, however, anti-apoptosis genes are also up-regulated [24-26]. Thus, the eosinophilic cytoplasm is characterized by co-existence of apoptotic and anti-apoptotic mechanisms and retains its activity as a result of balance between apoptosis and anti-apoptosis.

cDNA microarray analysis indicated that some other genes may be involved in the apoptosis occurred in infected muscle cells, for example, Bcl6, clusterin (CLU), $\mathrm{Bcl} 2$-interacting killer-like (Biklk), programmed cell death protein 11 (Pdcd11), proline dehydrogenase 1 (Prodh1) and Prodh2 [11]. These genes function in inducing apoptosis or prevent apoptosis, and are related with cell growth and survival [37-46]. The up-regulated expressions of these genes suggest that they engage in the apoptosis and anti-apoptosis in infected muscle cell through different mechanisms.

\section{Satellite cell activation, proliferation and differentiation}

Each myofiber is surrounded by a single sheet (basal lamina). Within this sheet, there is another cell, the satellite cell. As mentioned in the previous paragraph, satellite cells are myoblasts which differentiate to a new muscle cell when the muscle is injured. Muscle damage triggers such activation and proliferation of satellite cells. Thus, the satellite cells can continuously supply the new muscle

Table I: Expression change of the genes related to apoptosis after Trichinella infection

\begin{tabular}{|c|c|c|c|}
\hline \multirow[t]{2}{*}{ Gene Name } & \multirow[t]{2}{*}{ Description } & \multicolumn{2}{|c|}{ Expression change } \\
\hline & & Ts & $\mathrm{Tp} \mathrm{p}^{\mathrm{a}}$ \\
\hline tumor necrosis factor receptor I (TNFRI) & TNF-medicated apoptosis & $\uparrow$ & $\uparrow$ \\
\hline proline dehydrogenase (oxidase) 2 (Prodh2) & mitochondria-mediated apoptosis & $\uparrow$ & $\uparrow$ \\
\hline Bcl2-interacting killer-like (Biklk) & Bcl family protein; induction of apoptosis & $\uparrow$ & $\uparrow$ \\
\hline B-cell leukemia/lymphoma 6 (Bcl6) & apoptosis; caspase activation & $\uparrow$ & $\uparrow$ \\
\hline programmed cell death protein II (PdcdII) & hydrolase activity; apoptosis & $\uparrow$ & $\uparrow$ \\
\hline clusterin $(\mathrm{CLU})$ & anti- or proapoptotic activity & $\uparrow$ & $\uparrow$ \\
\hline nuclear protein I (Nupr I) & induction of apoptosis; response to stress & $\uparrow$ & $\mathrm{NCb}$ \\
\hline p53 & apoptosis, DNA repair, cell cycle arrest & $\uparrow$ & $\uparrow$ \\
\hline p2l & apoptosis, cell cycle arrest & $\uparrow$ & $\uparrow$ \\
\hline MDM2 & apoptosis, negative regulator of p53 & $\uparrow$ & $\uparrow$ \\
\hline $\mathrm{Bcl}-2$ associated protein $\mathrm{X}(\mathrm{BAX})$ & mitochondria-medicated apoptosis & $\uparrow$ & $\uparrow$ \\
\hline Apoptotic protease activating factor I (ApafI) & mitochondria-medicated apoptosis & $\uparrow$ & $\uparrow$ \\
\hline Caspase 9 & mitochondria-medicated apoptosis & $\uparrow$ & $\uparrow$ \\
\hline protein kinase $B(P K B)$ & promote cell survival and prevent apoptosis & $\uparrow$ & $\uparrow$ \\
\hline tumor necrosis factor-alpha (TNF) & cell proliferation, differentiation, apoptosis & $\uparrow$ & UR c \\
\hline TNFR I-associated via death domain (TRADD) & adaptor of TNFRI mediated apoptosis & $\uparrow$ & UR \\
\hline Caspase 8 & apoptosis & $\uparrow$ & UR \\
\hline Caspase 3 & apoptosis & $\uparrow$ & UR \\
\hline TNF receptor-associated factor 2 (Traf2) & mediator of anti-apoptotic in TNFRI signal & $\uparrow$ & UR \\
\hline Receptor interactive protein (RIP) & mediator of anti-apoptotic in TNFRI signal & $\uparrow$ & UR \\
\hline
\end{tabular}

a: Ts: Trichinella spiralis; Tp: T. pseudospiralis

b: NC: no change

c: UR: no result 
cells even if the muscle is damaged. Some of these events are common with the myopathy provoked by Trichinella infection.

\section{Satellite cell in muscle regeneration}

Activation of muscle satellite cells appears to be an important step in the ability of muscle to regenerate. In the course of muscle regeneration, satellite cells first exit their normal quiescent state to start proliferating. After several rounds of proliferation, a majority of the satellite cells differentiate and fuse to form new myofibers or to repair damaged ones $[22,47]$. The process of satellite cell activation and differentiation during muscle regeneration is reminiscent of embryonic muscle development. In particular, the critical roles of the myogenic regulatory factors (MRFs: MyoD, myogenin, Myf5 and MRF4) and paired box genes (Pax 3 and Pax 7) are observed in both processes [48-50].

At the molecular level, activation of satellite cells is characterized by the rapid up-regulation of two MRFs, Myf5 and MyoD. Following muscle injury, MyoD and Myf5 upregulation appears early, and the activation of expression has been observed in various in vivo models for muscle regeneration and in various types of muscle [15,51-55]. MRF4 likely plays a role in maturation of regenerated myofibers. After the satellite cell proliferation phase, myogenin and MRF4 are up-regulated in cells beginning their terminal differentiation program. This is followed by the activation of cell cycle arrest protein p21 (cyclin-dependent kinase inhibitor 1A) and permanent exit from the cell cycle. The differentiation program is then completed with the activation of muscle specific proteins, such as MGC, and fusion to damaged muscle cells [56-59].

\section{Satellite cell in nurse cell formation}

Activation and proliferation of satellite cells occur in Trichinella infected muscles. A linear alignment of satellite cell nuclei is observed in the periphery of infected cells along their long axis of myofibers [5]. Myogenic regulatory factors (MyoD and myogenin) were over-expressed in infected muscle tissue of both T. spiralis and T. pseudospiralis infection, and the MyoD factor is highly expressed in the satellite cells of infected muscle cells [6].

cDNA microarray analysis has revealed that several other genes important for differentiation of satellite cells are upregulated during nurse cell development, as shown in Table 2, including Pax7, desmin, M-cadherin, Numb, manic fringe homolog (Mfng), Deltex 1 (Dtx1), myocytespecific enhancer factor 2C (MEF2), pre B-cell leukemia transcription factor $1(\mathrm{Pbx} 1)$, and nuclear factor of activated T cells (NFAT) [9-11].
Pax7 and desmin are specifically expressed in quiescent and activated muscle satellite cells and have been used as a molecular marker of muscle satellite cell $[60,61]$. The over-expression of Pax7 and desmin indicate that the satellite cells in infected muscle were activated and in proliferating.

M-cadherin, a marker of satellite cells and expressed at the cell surface of proliferating satellite cells, is highly expressed during prenatal development in myogenic cells of somatic origin, in myoblasts forming small muscle bundles in developing limb bud, in myoblasts, and in regenerating skeletal muscle $[62,63]$. An over-expression of M-cadherin was observed in T. pseudospiralis, but not in T. spiralis, thus suggesting the differential expression may play a role in the pathology induced by T. pseudospiralis by regulating the satellite cells of infected muscle cells.

Multiple mechanisms may involve in the regulation of differentiation initialed by Trichinella infection. One of those is the Notch signal pathway. Notch signaling plays an important role in tissue morphogenesis both during development and during postnatal regeneration of skeletal muscle [64]. Numb, Mfng and Dtx1, the regulators of the Notch signaling pathway [64-67], were up-regulated in both T. spiralis and T. pseudospiralis infected muscle tissues, suggesting that this signaling pathway is likely to be involved in the activation and differentiation of satellite cells or infected muscle cells.

The factor MEF2 is involved in the activation of musclespecific gene expression, and acts in concert with MRFs in muscle cell differentiation $[12,68]$. The factor NFAT plays a role in regulation of MRFs expression in satellite cells [69].

The factor MRF4 behaves differently. During muscle cell regeneration, MRF4 plays a role in the maturation of regenerated myofiber $[58,68]$. After trauma there is an upregulation of MRF4 after initiating a terminal differentiation program. In Trichinella infection, no expression change of MRF4 was observed during the nurse cell formation [6]. This difference may reflect the fact that the satellite cell cannot be "matured" as a new muscle cell, but instead de-differentiates to the nurse cell.

\section{Roles of insulin-like growth factor (IGF) in satellite cell activation and differentiation}

The IGF I signaling pathway in muscle biology has been an interesting issue as a result of the fact that IGF I induces both proliferation and differentiation via the type I receptor [70]. As a key factor, IGF-I involves proliferation and differentiation of satellite cells during muscle regeneration [71-73]. There is over-expression of IGFs, for example, IGF I, IGF I receptor, IGF binding protein 2 (IGFBP2), 
Table 2: Expression change of the genes related to muscle development, myogenesis and regeneration after Trichinella infection

\begin{tabular}{|c|c|c|c|}
\hline \multirow[t]{2}{*}{ Gene Name } & \multirow[t]{2}{*}{ Description } & \multicolumn{2}{|c|}{ Expression change } \\
\hline & & Ts & $T p^{a}$ \\
\hline MyoD & skeletal muscle development and differentiation & $\uparrow$ & $\uparrow$ \\
\hline myogenin & skeletal muscle development and differentiation & $\uparrow$ & $\uparrow$ \\
\hline galectin 3 & skeletal muscle development & $\uparrow$ & $\uparrow$ \\
\hline Casitas B-lineage lymphoma (CBL) & suppressing transformation; muscle degeneration & $\uparrow$ & $\uparrow$ \\
\hline manic fringe homolog (Drosophila) (Mfng) & promoting differentiation by repression of Notch signaling & $\uparrow$ & $\uparrow$ \\
\hline eyes absent 2 homolog (Drosophila) (Eya2) & muscle development; myogenesis & $\uparrow$ & $\uparrow$ \\
\hline ski proto-oncogene; (c-ski) & cell differentiation and transformation & $\uparrow$ & $\uparrow$ \\
\hline insulin-like growth factor binding protein 4 (Igfbp4) & skeletal muscle development & $\uparrow$ & $\uparrow$ \\
\hline galectin I & myoblast differentiation and fusion; myotube growth & $\uparrow$ & $\uparrow$ \\
\hline dickkopf homolog 4 (Dkk4) & limb development & $\uparrow$ & $\uparrow$ \\
\hline bone morphogenetic protein 4 (Bmp4) & skeletal development; angiogenesis & $\uparrow$ & $\uparrow$ \\
\hline T-box 15 (Tbx।5) & limb development of limb & $\uparrow$ & $\uparrow$ \\
\hline pre B-cell leukemia transcription factor I (Pbxl) & embryonic development and differentiation; & $\uparrow$ & $\uparrow$ \\
\hline numb gene homolog (Drosophila) (Numb) & cell proliferation and differentiation in muscle development & $\uparrow$ & $\uparrow$ \\
\hline paired box gene 7 ( $\mathrm{Pax} 7)$ & development; organogenesis; cell differentiation & $\uparrow$ & $\uparrow$ \\
\hline myocyte enhancer factor $2 \mathrm{C}$ (MEF2C) & regulation of transcription; myogenic differentiation & $\uparrow$ & $\uparrow$ \\
\hline nuclear factor of activated T cells (NFAT) & transcriptional activator activity; cytokine production & $\uparrow$ & $\uparrow$ \\
\hline deltex I homolog (Drosophila) (Dtxl) & myogenesis, muscle development and proliferation & $\uparrow$ & $\uparrow$ \\
\hline desmin & cytoskeleton organization; muscle contraction & $\uparrow$ & $\uparrow$ \\
\hline homeo box, msh-like I (MsxI) & organ morphogenesis; skeletal development & $\uparrow$ & $\uparrow$ \\
\hline myeloid leukemia factor I (MLFI) & cell differentiation; development; hemopoiesis & $\downarrow$ & $\downarrow$ \\
\hline chordin-like 2 (Chrdl2) & skeletal development & $\uparrow$ & $\mathrm{NCb}$ \\
\hline paired box gene $3(\mathrm{Pax} 3)$ & cell migration and proliferation; muscle development & $\uparrow$ & NC \\
\hline Transforming growth factor 2 & controls proliferation, differentiation and transformation & $\uparrow$ & $\uparrow$ \\
\hline $\operatorname{smad} 2$ & Transducer of TGF signal pathway, cell proliferation and differentiation & $\uparrow$ & NR c \\
\hline $\operatorname{smad} 4$ & Transducer of TGF signal pathway, cell proliferation and differentiation & $\uparrow$ & NR \\
\hline
\end{tabular}

a: Ts: Trichinella spiralis; Tp: T. pseudospiralis

b: NC: no change

c: UR: no result

IGFBP4 and IGFBP5 $[9,11]$, in Trichinella infected muscle tissue, which suggests that these factors likely play an important role in nurse cell formation.

The binding of IGF-I to the IGF-I receptor induces phosphorylation of the receptor, which then mainly function at 3 different levels.

First, IGF-I has been shown to activate myoblast proliferation through the mitogen activated protein kinase (MAP kinase) signaling pathway, which activates cell cycle progression markers, such as cyclin $\mathrm{D}$, cyclin-dependent kinase 4 (CDK4), c-fos, c-jun [74-76]. It was found that in Trichinella infected muscle, expression of IGF-I, IGF-I receptor, IGFBPs, MAP kinase kinase, cyclin D2, cyclin D3, CDK4 and $c$-jun were up-regulated $[9,11]$, suggesting that IGF-I likely plays role in the proliferation of satellite cells and cell cycle reentry of infected muscle cell during nurse cell formation through MAP kinase signaling (Fig 3).

Secondly, IGF induces differentiation of myoblast via the phosphatidylinositol 3-kinase (PI3-K) pathway, which activates Akt and subsequently modulates expression of terminal muscle differentiation markers, such as p21, MyoD, myogenin and MEF2 [74,75,77]. In Trichinella infection, expression of Akt, MyoD, myogenin and p21 was greatly increased during 13-28 dpi [6,24-26]. Immunostaining indicated that increased expression of Akt is limited in the eosinophilic cytoplasm which originates from satellite cells [24], and MyoD is limited in the satellite cells of infected muscle cells [6]. The cDNA Microarray analysis showed that the expression of MEF2 was up-regulated in the T. spiralis infected muscle tissues $[9,11]$. Therefore, through the PI3-K-Akt signaling pathway, IGFI is likely to play a role in the differentiation of activated satellite cell after Trichinella infection (Fig 3).

Thirdly, through the PI3-K/Akt signaling pathway, IGF-I also has an effect on cell survival by inhibiting proapoptotic proteins of Bcl-2 family (Bax and Bad), and by inducing anti-apoptotic proteins of Bcl-2 family (Bcl-X) $[78,79]$. In Trichinella infection, there was an increased expression of Bax protein in the basophilic cytoplasm of infected muscle cell at an early stage of infection (18 dpi), but the expression decreased to an undetectable level at a late 


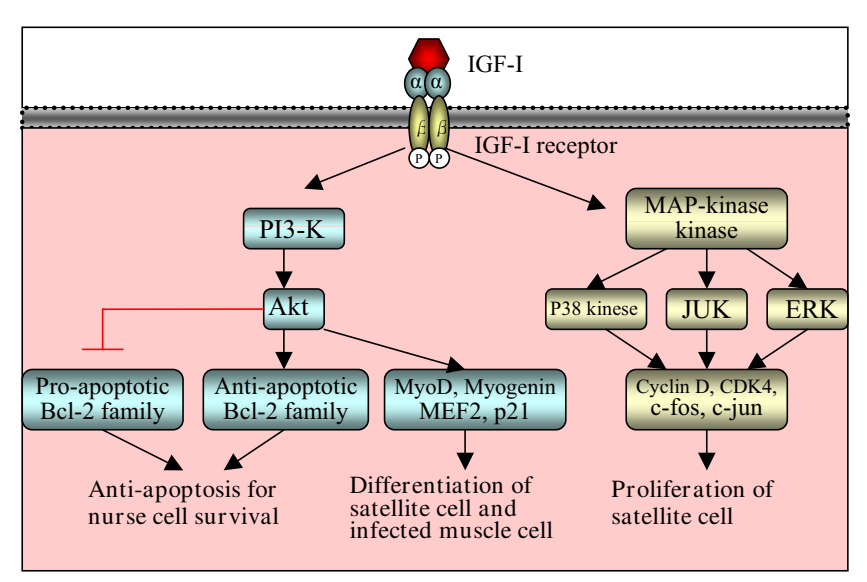

Figure 3

Schematic illustration of IGF-I signaling pathway in nurse cell formation. The binding of IGF-I to IGF-I receptor induces phosphorylation of the receptor, which acts through MAPkinase kinase and/or PI3-K. Via the MAP kinase pathway, it activates cell cycle progression genes (cyclin D, cdc4, c-fos and c-jun) which proliferates satellite cells after Trichinella infection. Via the PI3-K/Akt pathway, it modulates the expression of muscle differentiation genes (p2I, MyoD, Mef2 and myogenin) which involve in the redifferentiation of satellite cells and differentiation of infected muscle cells. Also the activation of $\mathrm{PI3}-\mathrm{K} / \mathrm{Akt}$ inhibits proapoptosis by $\mathrm{Bcl}-2$ family (Bax, Bad) and induces anti-apoptotic function by $\mathrm{Bcl}-2$ family $(\mathrm{Bcl}-\mathrm{X})$, which contributes to the survival of nurse cells. This figure referred the review by Mourkioti and Rosenthal [70].

stage of infection (48 dpi) [24]. Kinetics of this gene expression corresponded to the process of nurse cell formation [24-26]. Therefore, IGF-I might be involved in modulating apoptosis and anti-apoptosis, leading to the survival of infected muscle cells (Fig 3).

\section{Factors for cell cycle reentry and arrest}

Following invasion of new born larvae, the infected muscle cell withdraws from the G0 cell cycle and re-enters the cell cycle [7]. The enlarged nuclei possess an approximate $4 \mathrm{~N}$ complement of DNA. The increased DNA synthesis is completed by $5 \mathrm{dpi}$, and then is suspended throughout the course of infection, which indicated that cell cycle is arrested at G2/M. The molecular mechanism of cell cycle reentry and arrest during infection remains unclear, but recent studies have provided further insight.

The phenomenon of cell cycle arrest may be unique to the nurse cell formation because no comparative phenomena were reported in muscle genesis or muscle repair processes, so far as the present authors are aware.
I. The genes related to regulation of cell cycle in nurse cell formation As shown in Table 3, expression change of many cell cyclerelated factors was observed in Trichinella infected muscle tissue, for example, retinoblastoma (Rb), CDK4, cyclin C, cyclin B2, cyclin D2 and cyclin D3, CLU, G0/G1 switch gene 2 (GOS2), inhibitor of DNA binding 2 (Id2), myeloblastosis oncogene (Myb), and N-myc downstream regulated gene 2 (Ndrg2) [9,11]. These factors have already been elaborated by other authors. For example, different cyclins bind specifically to different CDKs to form distinct complexes at specific phases of the cell cycle and thereby drive the cell from one stage of the cycle to another [80,81]. Upon stimulation, D-type cyclins assemble CDK4 and CDK6 to form complexes, which facilitate cells to exit from the G0 phase and re-enter the cell cycle of G1 cell cycle phase [82-84]. Therefore, increased expression of cyclin D2, cyclin D3 and CDK4 is probably involved in the cell cycle reentry after infection.

On the other hand, up-regulated expression of retinoblastoma (Rb), p21, p27 (cyclin-dependent kinase inhibitor 1B) and p57 (cyclin-dependent kinase inhibitor 1C) may be responsible for the cell cycle arrest of infected muscle cell $[9,26]$. These kinds of factors are known to play an important role in the growth arrest of differentiating cells, because they specifically inhibit CDKs, which leads to the withdrawal of cells from the cycle and differentiation [8587].

As a cyclin-dependent kinase inhibitor, p21 is a critical factor in cell cycle arrest at G2/M [88]. Cells deficient in p21 are unable to maintain stability of the cycle arrest [89]. Introduction of non-functional p21 or a p21 antisense oligonucleotide diminished the G2/M arrest phenotype in cells [90,91]. In Trichinella infection, expression of p21 was up-regulated, which increased from $13 \mathrm{dpi}$, reached a peak at $18 \mathrm{dpi}$ and then decreased at late stage of infection $[25,26]$. Therefore, p21 is an important factor in cell cycle arrest during nurse cell formation.

The expression changes of several other cell cycle-related genes were also observed in Trichinella infection, for example, CLU and G0S2. The expression of CLU was upregulated, while the expression of G0S2 was down-regulated [11]. It is known that, both genes play roles in regulating the cell cycle. An over-expression of CLU resulted in an increased accumulation of cells at the G0/G1 phases of the cell cycles, accompanied by slow down of cell cycle progression and a reduction of DNA synthesis [92]. High level of CLU causes cell cycle arrest $[93,94]$. G0S2 is transiently induced upon re-entry of cells into the G1 phase of the cell cycle $[95,96]$. Therefore, UCL and G0S2 may be involved in the arrest of infected muscle cells. 
Table 3: Expression change of the genes related to cell cycle regulation after Trichinella infection

\begin{tabular}{|c|c|c|c|}
\hline \multirow[t]{2}{*}{ Gene Name } & \multirow[t]{2}{*}{ Description } & \multicolumn{2}{|c|}{ Expression change } \\
\hline & & Ts & $T p^{a}$ \\
\hline retinoblastoma I (Rbl) & negative regulation of cell growth and progression via cell cycle & $\uparrow$ & $\uparrow$ \\
\hline ring-box I (Rbxl) & cell cycle regulation of GI/S transition & $\uparrow$ & $\uparrow$ \\
\hline cyclin-dependent kinase inhibitor IA (P2I) & cell cycle arrest; negative regulation of cell proliferation & $\uparrow$ & $\uparrow$ \\
\hline cyclin-dependent kinase 4 (CDK4) & cell cycle; cell proliferation; GI/S transition & $\uparrow$ & $\uparrow$ \\
\hline G0/GI switch gene 2 (G0s2) & regulation of progression through cell cycle & $\downarrow$ & $\downarrow$ \\
\hline Granulin & Mitogen, cell cycle progression, cell motility & $\uparrow$ & $\mathrm{NC}$ \\
\hline cyclin A2 & $\mathrm{GI} / \mathrm{S}$ and $\mathrm{G} 2 / \mathrm{M}$ transitions, regulator of $\mathrm{CDC} 2$ or $\mathrm{CDK} 2$ kinases & $\uparrow$ & NC \\
\hline cyclin C & regulation of cell cycle & $\uparrow$ & NC \\
\hline Cyclin D3 & cell cycle GI/S transition, regulator of CDK4 or CDK6 & $\uparrow$ & UR a \\
\hline Cyclin D2 & cell cycle GI/S transition, regulator of CDK4 or CDK6 & $\uparrow$ & UR \\
\hline Cyclin B2 & Cell cycle regulation, TGF beta-mediated cell cycle control & $\uparrow$ & UR \\
\hline cyclin EI & $\mathrm{GI} / \mathrm{S}$ transitions, regulator of $\mathrm{CDC2}$ & $\uparrow$ & UR \\
\hline myeloblastosis oncogene (Myb) & regulation of cell cycle; GI/S transition of mitotic cell cycle & NC & $\uparrow$ \\
\hline CDC20 & regulation of cell cycle & $\uparrow$ & UR \\
\hline cyclin-dependent kinase inhibitor IB (P27) & $\begin{array}{l}\text { controls cell cycle progression at GI, prevents activation of cyclin E-CDK2 or } \\
\text { cyclin D-CDK } 4 \text { complexes }\end{array}$ & $\uparrow$ & UR \\
\hline Cullin 3 (Cul3) & Cell cycle arrest, GI/S transition of cell & NC & $\downarrow$ \\
\hline Cell division cycle 5 (Cdc5) & positive regulator of cell cycle G2/M progression & NC & $\downarrow$ \\
\hline
\end{tabular}

a: Ts: Trichinella spiralis; Tp: T. pseudospiralis

b: NC: no change

c: UR: no result

\section{Involvement of TGF- $\beta$ signaling pathway in cell cyclearrest}

One of the important signaling pathways involved in cell cycle arrest is the TGF- $\beta$ (transforming growth factor) signaling pathway. TGF- $\beta$ is a ubiquitous cytokine that regulates cell differentiation, proliferation, apoptosis and morphogenesis [97]. Through a series of Smad proteins (Smad 2, Smad 3 and Smad 4), the TGF- $\beta$ signaling pathway causes cells to cease proliferation and to down-regulates the genes which promote cell cycle progression though the $S$ phase, leading to the arrest of the cell cycle (Fig 4).

Recent studies indicated that the expression of the TGF- $\beta$ signaling pathway factor genes (TGF- $\beta, \operatorname{Smad} 2$ and Smad4) and $c$-ski, the repressor of the signal pathway, were up-regulated in Trichinella infected muscle cells [911]. The analysis of expression kinetics showed that the expression of these genes increased at $13 \mathrm{dpi}$, reached a peak at 23 dpi and then decreased, which is corresponding to the process of nurse cell development. Immunohistochemical analysis indicated that in the early stages of infection, the increased expression of the c-Ski protein was limited to the eosinophilic cytoplasm, while at a later stage of infection the c-Ski protein was limited to the enlarged nuclei in the basophilic cytoplasm, rather than the eosinophilic cytoplasm [10]. These findings provide evidence that the TGF- $\beta$ signaling pathway is involved in the cell cycle arrest and transformation of infected muscle cells.

\section{De-differentiation of infected muscle cell and origin of hypertrophy} nuclei

The invasion of new born larvae induces the de-differentiation of infected muscle cell, with features of loss of muscle cell characteristics, change in muscle gene expression and up-regulated expression of cell differentiation related genes (such as MyoD, myogenin, MEF2, Pbx1, Numb, Pax7, Msx and NFAT) in infected muscle tissues [7,9,98100]. Upon stimulation of larva invasion, infected muscle cells withdraw from the G0 cell cycle and re-enter the cell cycle.

It is commonly thought that newly regenerated fibers are produced by the fusion of activated satellite cells during muscle regeneration. Studies, however, indicated that terminally differentiated myotubes can de-differentiate and Msx genes can be one of the factors to contribute to this process [101-105]. The early event in the de-differentiation of the infected muscle cell may follow the mechanism of de-differentiation in muscle cell regeneration, which was characterized by similar phenomena, for example, the losing of myofibrillar structure, enlarged nuclei and cell cycle re-entry $[7,28,98,106-108]$. The up-regulated expression of Msx1 and Msx2 in infected muscle tissue supports the proposal that de-differentiation of infected muscle provides hypertrophic nuclei $[9,11]$.

cDNA microarray analysis showed that some other genes may be involved in the de-differentiation of infected mus- 


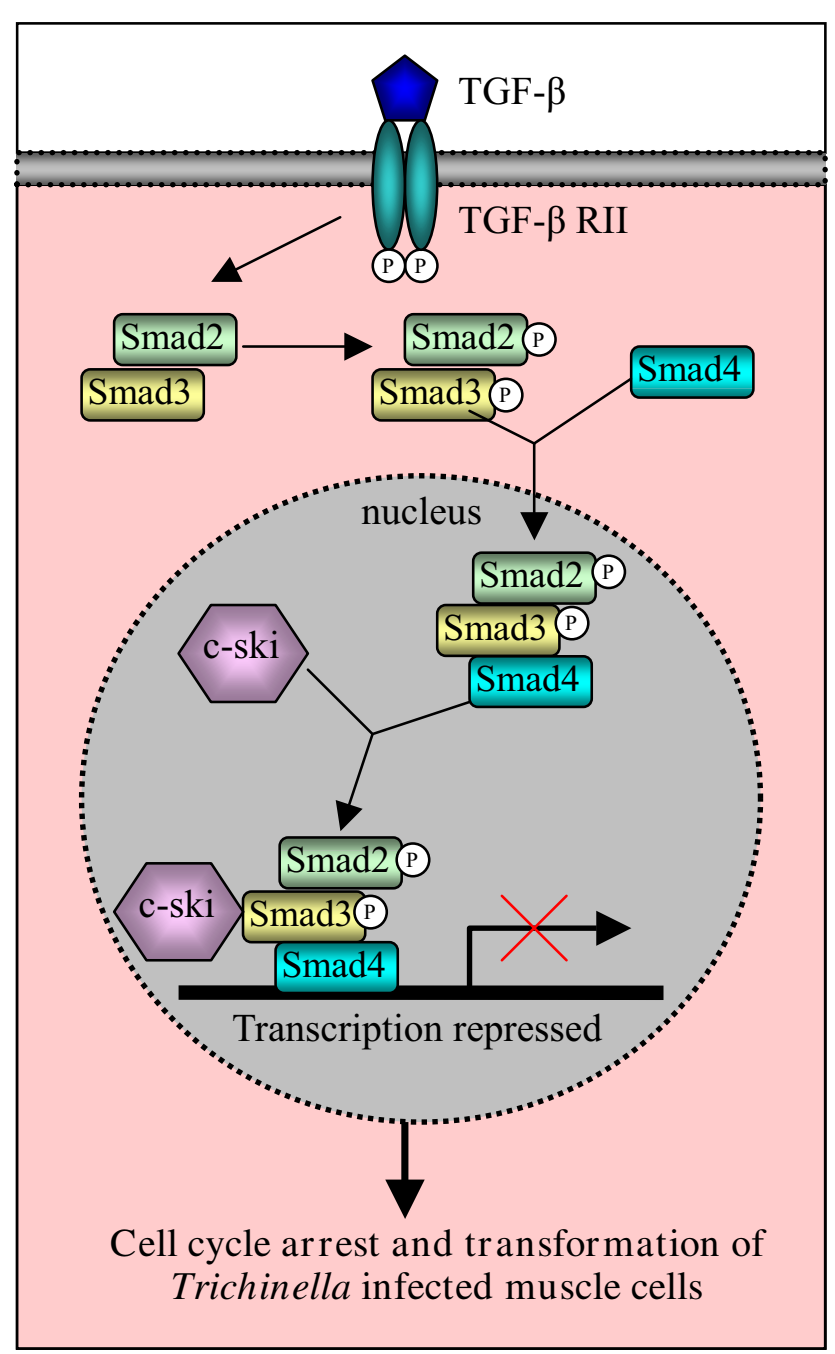

\section{Figure 4}

Schematic illustration of the involvement of c-Ski and TGF- $\beta$ signaling pathway in nurse cell formation. Binding of TGF- $\beta$ by the type II receptor on the cell surface initiates a cascade of signaling events. Activated type I receptor phosphorylates Smad 2 and Smad3 in the cytoplasm, which forms a complex with Smad4. The Smad2/3/4 complex moves to the nucleus and functionally collaborates with distinct transcription factors to turn on or off transcription of many TGF- $\beta$-responsive genes. C-Ski acts as a co-repressor to turn off the transcription, which results in the cell cycle arrest and transformation of Trichinella infected muscle cells. This figure referred the review by Shi and Massague [97].

cle cells, for example, galectin 1 and galectin 3, Nanog [11]. The expression of galectin 1 and galectin 3 were upregulated in Trichinella infection. Both genes induce a non-committed myogenic cell within the dermis to expression myogenic markers, increases the terminal differentiation of committed myogenic cells and play a role in skeletal muscle determination, differentiation and regeneration [109-111], suggesting their potential involvement in the de-differentiation of infected muscle cells.

There are as many as 100 hypertrophic nuclei that are located in the central part of basophilic cytoplasm. The origin of the hypertrophic nuclei was suggested to be from myonuclei, not from satellite cells $[7,8]$. Recent findings, however, have demonstrated the presence of multipotential stem cells in various adult tissues. Adult stem cells isolated from various tissues appear to differentiate into multiple lineages depending on environmental cues [112116]. Adult muscle-derived stem cells have been shown to differentiate into muscle cell in vitro and to contribute to muscle regeneration in vivo [105,109,117]. These reports suggest that the muscle derived-stem cells should be further examined as an additional source of the hypertrophic nuclei in infected muscle cell.

As a response of muscle cells to the damage by Trichinella larva, de-differentiation occurs. However, the process of muscle cell de-differentiation is not followed by the same process as in muscle cell regeneration after trauma, but results in creating the environment for larva to develop, grow and survive. Trichinella larvae grow within the muscle cell at astonishing speed, increasing its volume by about $40 \%$ per day [23]. Therefore, this kind development and growth require high consumption of nutrients. The metabolism of protein, glucose and fat in the nurse cell is increased during nurse cell formation [118]. Larvae utilize the de-differentiation of muscle cell to create a suitable environment to nurse it.

\section{Collagen capsule}

A capsule wall is a prominent non-cellular structure and, as such, one may think it is unique only to Trichinella infection, and not shared by the normal muscle cell. An ultrastructural study, however, showed the capsule wall as a sort of simple thickening of the basal lamina that normal muscle cells have. In normal muscles, cellular components, muscle cells and their associated myoblasts (satellite cell) are wrapped together with a single non-cellular sheet, the basal lamina.

The capsule wall has two layers; the inner and outer. The former is produced by the nurse cell and the latter is produced by fibroblasts around the capsule. The spatial relationship among the non-cellular structure and cellular components remains the same before and after capsule formation.

\section{Parasites utilize cell-biological-systems of hosts to establish parasitism}

In this review, the analogy between the processes of nurse cell formation and muscle cell repair has been empha- 
sized. At least the earliest events mobilizing satellite cells seem to be common, but the fate of the proliferated myoblast cell is different. In the former case, the satellite cell differentiates to the muscle cell, but it mis-differentiates to the nurse cell in the latter case. The idea that comes to mind is that Trichinella, in order to make its own home, basically utilizes the cell-biological-system of the host which is equipped for the purpose of muscle cell repairing. Since the satellite cell is a progenitor cell located within the capsule wall, a new cell can be continuously supplied from the myoblast, even if the present nurse cell dies. This explains why the nurse cell looks intact and active for years in spite of intracellular parasitism. Thus Trichinella can take advantage of the host for its own survival.

How the parasite takes advantage of the host cell biological system to build its home is an interesting issue for parasitologists. Despommier [3] proposed "parakines" as messengers to carry out the communication between parasite and host cells by molecular cross-talking in order to provide life-long coexistence. It was hypothesized that the parakines direct specific cellular behavior by effecting signaling pathways, as cytokines are doing in mammalian host cell.

Thus far, many efforts have been made to identify and characterize the parakines, some of which have provided indirect evidence in support of the hypothesis. Early studies indicated that Trichinella antigenic epitopes were detected in the hypertrophy nuclei of infected muscle cell $[119,120]$. Some nuclear antigens (for example, 79, 86 and $97 \mathrm{kDa}$ proteins) which react with monoclonal antibody to Trichinella excretory-secretory (ES) products have been identified and characterized, and their potential effects in regulating nuclear function of the host cell have been studied [121-123]. Vassilatis et al. [100] cloned a specific $43 \mathrm{kDa}$ glycoprotein of muscle larva ES which belongs to the basic helix-loop-helix (bHLH) DNA-binding protein family. The bHLH family includes myogenic regulatory factors, suggesting that the $43 \mathrm{kDa}$ ES protein may play a role in the differentiation of host cells. Mak and Ko [124] found a novel DNA-binding protein from ES products, which may function in host genomic reprogramming. Nagano et al. [125-127] cloned and characterized several ES proteins, including serine proteinase, serine proteinase inhibitor and Rcd 1 (Required cell differentiation 1) - like protein which may involve in host muscle cell differentiation. Tan et al. [128] and Wu et al. [129] reported that Trichinella produces macrophage migration inhibitor (MIF), a cytokine which may protect the parasite from host immune attack.

Though many proteins of Trichinella ES products have been cloned and characterized, their precise effects on each step of nurse cell formation (activation, proliferation and re-differentiation of satellite cell, de-differentiation of infected muscle cell) is still unclear. Some of the ES proteins of Trichinella are stage specific. Most of the investigated proteins are those produced by late stage of larvae (for example, over 30 days). More attention should be paid to ES products from other Trichinella stages. Jasmer and Neary [8] reported that full stichocyte development is not required for host cell cycle re-entry, suggesting that the products of parasitism genes responding to reprogramming host genetic transcription are produced at a very early stage of infection. The proteins shed by the parasite at an early stage of infection seem to be more relevant for determining the mechanism of nurse cell formation.

\section{Conclusion}

The process of nurse cell formation is complex. Many aspects of it are still unknown. The response of infected muscle cell at early stage is quite similar to that occurring in myogensis and muscle regeneration, including the activation, proliferation and differentiation of satellite cell, and cell cycle re-entry. Many genes that play important roles in muscle myogenesis and regeneration are up-regulated and have been proposed as candidate ones involved in nurse cell formation. Some of these genes have been confirmed to be responding to the process of nurse cell development. At the late stage of nurse cell formation, development of infected muscle goes along with the demands of the larva: arrest of cell cycle, the change of basophilic and eosinophilic cytoplasm, involvement of apoptosis and anti-apoptosis and finally transforming into nurse cell. It could be proposed that the process at the beginning is a response of host cells to larval invasion, while the process at a later stage it is reforming or restructuring of host cell processes by larva. Therefore, the present review gives an outline of nurse cell formation, especially on the molecular mechanisms involved.

\section{Competing interests}

The authors declare that they have no competing interests.

\section{Authors' contributions}

All authors engaged in drafting manuscript and approved the final version.

\section{Acknowledgements}

This work was supported by a Grant-in-Aid for Scientific Research (I7590370) from the Ministry of Education, Culture, Sports, Science and Technology of Japan.

\section{References}

I. Maier DM, Zaiman $\mathrm{H}$ : The development of lysosomes in rat skeletal muscle in trichinous myositis. J Histochem Cytochem 1966, 14:396-400.

2. Steward GL, Read CP: Change in RNA in mouse trichinosis. J Parasitol 1973, 59:997-1005.

3. Despommier DD: How does Trichinella spiralis make itself at home? Parasitol Today 1998, 14:318-323. 
4. Wozniak AC, Kong J, Bock E, Pilipowicz O, Anderson JE: Signaling satellite-cell activation in skeletal muscle: markers, models, stretch, and potential alternate pathways. Muscle Nerve 2005 3I:283-300.

5. Matsuo A, Wu Z, Nagano I, Takahashi Y: Five types of nuclei present in the capsule of Trichinella spiralis. Parasitology 2000 | 2 |:203-210.

6. Wu Z, Matsuo A, Nakada T, Nagano I, Takahashi Y: Different response of satellite cells in the kinetics of myogenic regulatory factors and ultrastructural pathology after Trichinello spiralis and T. pseudospiralis infection. Parasitology 200I, 123:85-94.

7. Jasmer DP: Trichinella spiralis infected skeletal muscle cells arrest in $\mathbf{G}_{2} / \mathbf{M}$ and cease muscle gene expression. J Cell Biol 1993, I 2 I:785-793.

8. Jasmer DP, Neary SM: Trichinella spiralis: inhibition of muscle larva growth and development is associated with a delay in expression of infected skeletal muscle characteristics. Exp Parasitol 1994, 78:3 17-325.

9. Wu Z, Nagano I, Boonmars T, Takahashi Y: A spectrum of functional genes mobilized after Trichinella spiralis infection in skeletal muscle. Parasitology 2005, 130:56I-573.

10. Wu Z, Nagano I, Boonmars T, Takahashi Y: Involvement of the cSki oncoprotein in cell cycle arrest and transformation during nurse cell formation after Trichinella spiralis infection. Int J Parasitol 2006, 6: I I59-I I66.

II. Wu Z, Nagano I, Takahashi Y: Candidate genes responsible for common and different pathology of infected muscle tissues between Trichinella spiralis and $T$. pseudospiralis infection. Parasitol Int 2008, 57:368-78.

12. Parker MH, Seale P, Rudnicki MA: Looking back to the embryo: defining transcriptional networks in adult myogenesis. Nature Rev Genet 2003, 4:497-507.

13. Gros J, Manceau M, Thome V, Marcelle CA: Common somitic origin for embryonic muscle progenitors and satellite cells. Nature 2005, 435:954-958.

14. Relaix F, Rocancourt D, Mansouri A, Buckingham M: A Pax3/Pax7dependent population of skeletal muscle progenitor cells. Nature 2005, 435:948-953.

15. Zammit PS, Partridge TA, Yablonka-Reuveni Z: The skeletal muscle satellite cell: the stem cell that came in from the cold. J Histochem Cytochem 2006, 54:1177-1191.

16. Tidball JG: Inflammatory cell response to acute muscle injury. Med Sci Sports Exerc 1995, 27:1022-1032.

17. Tidball JG: Inflammatory processes in muscle injury and repair. Am J Physiol Regul Integr Comp Physiol 2005, 288:R345-353.

18. Shireman PK: The chemokine system in arteriogenesis and hind limb ischemia. J Vasc Surg 2007, 45:A48-56.

19. Robertson TA, Maley MA, Grounds MD, Papadimitriou JM: The role of macrophages in skeletal muscle regeneration with particular reference to chemotaxis. Exp Cell Res 1993, 207:32I-33I.

20. Merly F, Lescaudron L, Rouaud T, Crossin F, Gardahaut MF: Macrophages enhance muscle satellite cell proliferation and delay their differentiation. Muscle Nerve 1999, 22:724-732.

21. Arnold L, Henry A, Poron F, Baba-Amer Y, van Rooijen N, Plonquet A, Gherardi RK, Chazaud B: Inflammatory monocytes recruited after skeletal muscle injury switch into antiinflammatory macrophages to support myogenesis. J Exp Med 2007, 204:1057-1069.

22. Morgan JE, Partridge TA: Muscle satellite cells. Int J Biochem Cell Biol 2003, 35: II5I-II56.

23. Despommier DD, Aron L, Turgeon L: Trichinella spiralis: growth of the intracellular (muscle) larva. Exp Parasitol 1975, 37:108-116

24. Boonmars T, Wu Z, Nagano I, Takahashi Y: Expression of apoptosis-related factors in muscles infected with Trichinella spiralis. Parasitology 2004, I 28:323-332.

25. Boonmars T, Wu Z, Nagano I, Takahashi Y: Trichinella pseudospiralis infection is characterized by more continuous and diffuse myopathy than T. spiralis infection. Parasitol Res 2005, 97:13-20.

26. Boonmars T, Wu Z, Nagano I, Takahashi Y: What is the role of $\mathrm{p} 53$ during the cyst formation of Trichinella spiralis? A comparable study between knockout mice and wild type mice. Parasitology 2005, I 3 I:705-7 I2.
27. Wu Z, Nagano I, Boonmars T, Takahashi Y: Tumor necrosis factor receptor-mediated apoptosis in Trichinella spiralis-infected muscle cells. Parasitology 2005, I 3 I:373-38 |

28. Despommier DD, Symmans WF, Dell R: Changes in nurse cell nuclei during synchronous infection with Trichinella spiralis. J Parasitol 1991, 77:290-295.

29. Teppema JS, Robinson JE, Ruitenberg EJ: Ultrastructural aspects of capsule formation in Trichinella spiralis infection in the rat. Parasitology 1973, 66:291-296.

30. Baruch AM, Despommier DD: Blood vessels in Trichinella spiralis infections: a study using vascular casts. J Parasitol |99|, 77:99-103.

3I. Blotna-Filipiak M, Gabryel P, Gustowska L, Kucharska E, Wranicz MJ: Trichinella spiralis: induction of the basophilic transformation of muscle cells by synchronous newborn larvae. II. Electron microscopy study. Parasitol Res 1998, 84:823-827.

32. Wranicz MJ, Gustowska L, Gabryel P, Kucharska E, Cabaj W: Trichinella spiralis: induction of the basophilic transformation of muscle cells by synchronous newborn larvae. Parasitol Res 1998, 84:403-407.

33. Mancini M, Anderson BO, Caldwell E, Sedghinasab M, Paty PB, Hockenbery DM: Mitochondrial proliferation and paradoxical membrane depolarization during terminal differentiation and apoptosis in a human colon carcinoma cell line. J Cell Biol 1997, 138:449-469.

34. Desagher S, Martinou JC: Mitochondria as the central control point of apoptosis. Trends Cell Biol 2000, 10:369-377.

35. Gupta S: Molecular signaling in death receptor and mitochondrial pathways of apoptosis (Review). Int J Oncol 2003, 22:15-20.

36. Boonmars T, Wu Z, Nagano I, Nakada T, Takahashi Y: Differences and similarities of nurse cells in cysts of Trichinella spiralis and T. pseudospiralis. J Helminthol 2004, 78:7-16.

37. Yamochi T, Kaneita Y, Akiyama T, Mori S, Moriyama M: Adenovirusmediated high expression of BCL-6 in CV-I cells induces apoptotic cell death accompanied by down-regulation of BCL-2 and BCL-X(L). Oncogene 1999, I 8:487-494.

38. Kojima S, Hatano M, Okada S, Fukuda T, Toyama Y, Yuasa S, Ito H, Tokuhisa T: Testicular germ cell apoptosis in Bcl6-deficient mice. Development 200I, I 28:57-65.

39. Trougakos IP, Gonos ES: Clusterin/apolipoprotein J in human ageing and cancer. Int J Biochem Cell Biol 2002, 34: I430-I 448.

40. Criswell T, Klokov D, Beman M, Lavik JP, Boothman DA: Repression of IR-inducible clusterin expression by the $\mathrm{p} 53$ tumour suppressor protein. Cancer Biol Ther 2003, 2:372-380.

4I. Leskov KS, Klokov DY, Li J, Kinsella TJ, Boothman DA: Synthesis and functional analyses of nuclear clusterin, a cell death protein. J Biol Chem 2003, 278: I 1590-11600.

42. Miyake H, Hara I, Gleave ME, Eto H: Protection of androgendependent human prostate cancer cells from oxidative stressinduced DNA damage by overexpression of clusterin and its modulation by androgen. Prostate 2004, 61 :3 18-323.

43. Trougakso IP, So A, Jansen B, Gleave ME, Gonos ES: Silencing expression of the clusterin/apolipoprotein J gene in human cancer cells using small interfering RNA induces spontaneous apoptosis, reduced growth ability, and cell sensitization to genotoxic and oxidative stress. Cancer Res 2004, 64: $1834-1842$.

44. Coultas L, Bouillet P, Loveland KL, Meachem S, Perlman H, Adams JM, Strasser A: Concomitant loss of proapoptotic BH3-only Bcl-2 antagonists Bik and Bim arrests spermatogenesis. EMBO J 2005, 24:3963-3973.

45. Liu Y, Borchert GL, Surazynski A, Hu CA, Phang JM: Proline oxidase activates both intrinsic and extrinsic pathways for apoptosis: the role of ROS/superoxides, NFAT and MEK/ERK signaling. Oncogene 2006, 25:5640-5647.

46. Hu CA, Donald SP, Yu J, Lin WW, Liu Z, Steel G, Obie C, Valle D, Phang JM: Overexpression of proline oxidase induces prolinedependent and mitochondria-mediated apoptosis. Mol Cell Biochem 2007, 295:85-92.

47. Charge SBP, Rudnicki MA: Celllular and molecular regulation of muscle regeneration. Physiol Rev 2004, 84:209-238.

48. Zhao P, Hoffman EP: Embryonic myogenesis pathways in muscle regeneration. Dev Dyn 2004, 229:380-392.

49. Collins CA: Satellite cell self-renewal. Curr Opin Pharmacol 2006, 6:30I-6. 
50. Buckingham M: Skeletal muscle progenitor cells and the role of Pax genes. CR Biol 2007, 330:530-533.

5I. Fuchtbauer EM, Westphal H: MyoD and myogenin are coexpressed in regenerating skeletal muscle of the mouse. Dev Dyn 1992, 193:34-39.

52. Smith CK 2nd, Janney MJ, Allen RE: Temporal expression of myogenic regulatory genes during activation, proliferation, and differentiation of rat skeletal muscle satellite cells. J Cell Physiol 1994, I 59:379-385

53. Cooper RN, Tajbakhsh S, Mouly V, Cossu G, Buckingham M, ButlerBrowne GS: In vivo satellite cell activation via Myf5 and MyoD in regenerating mouse skeletal muscle. I Cell Sci 1999, I I 2:2895-290I.

54. Zador E, Bottka S, Wuytack F: Antisense inhibition of myoD expression in regenerating rat soleus muscle is followed by an increase in the mRNA levels of myoD, myf-5 and myogenin and by a retarded regeneration. Biochim Biophys Acto 2002, I 590:52-63.

55. Zammit PS, Heslop L, Hudon V, Rosenblatt JD, Tajbakhsh S, Buckingham ME, Beauchamp JR, Partridge TA: Kinetics of myoblast proliferation show that resident satellite cells are competent to fully regenerate skeletal muscle fibers. Exp Cell Res 2002, 281:39-49.

56. Yablonka-Reuveni Z, Rivera AJ: Temporal expression of regulatory and structural muscle proteins during myogenesis of satellite cells on isolated adult rat fibers. Dev Biol 1994, 164:588-603.

57. Walters EH, Stickland NC, Loughna PT: MRF-4 exhibits fiber typeand muscle-specific pattern of expression in postnatal rat muscle. Am J Physiol Regul Integr Comp Physiol 2000, 278:R I 38I - 384.

58. Zhou Z, Bornemann A: MRF4 protein expression in regenerating rat muscle. J Muscle Res Cell Motil 2002, 22:3 I I-3 I6.

59. Kassar-Duchossoy L, Gayraud-Morel B, Gomes D, Rocancourt D, Buckingham M, Shinin V, Tajbakhsh S: Mrf4 determines skeletal muscle identity in Myf5: Myod double-mutant mice. Nature 2004, 43I:466-47I.

60. Seale P, Rudnicki MA: A new look at the origin, function, and "stem-cell" status of muscle satellite cells. Dev Biol 2000, 218:115-124.

61. Hawke TJ, Garry DJ: Myogenic satellite cells: physiology to molecular biology. J Appl Physiol 200I, 91:534-55I.

62. Cornelison DD, Wold B]: Single-cell analysis of regulatory gene expression in quiescent and activated mouse skeletal muscle satellite cells. Dev Biol 1997, 191:270-283.

63. Wrobel E, Brzoska E, Moraczewski J: M-cadherin and beta-catenin participate in differentiation of rat satellite cells. Eur J Cell Biol 2007, 86:99-109.

64. Luo D, Renault VM, Rando TA: The regulation of Notch signaling in muscle stem cell activation and postnatal myogenesis. Semin Cell Dev Biol 2005, 16:6I2-22.

65. Hicks C, Johnston SH, diSibio G, Collazo A, Vogt TF, Weinmaster G: Fringe differentially modulates Jagged $I$ and Delta I signalling through Notch I and Notch2. Nat Cell Biol 2000, 2:5I5-520.

66. Yang LT, Nichols JT, Yao C, Manilay JO, Robey EA, Weinmaster G Fringe glycosyltransferases differentially modulate Notch 1 proteolysis induced by Deltal and Jagged I. Mol Biol Cell 2005 , 16(2):927-942.

67. Carlson ME, Conboy IM: egulating the Notch pathway in embryonic, adult and old stem cells. Curr Opin Pharmacol 2007. 7:R303-309.

68. Berkes CA, Tapscott SJ: MyoD and the transcriptional control of myogenesis. Semin Cell Dev Biol 2005, 16:585-595.

69. Friday BB, Pavlath GK: A calcineurin- and NFAT-dependent pathway regulates Myf5 gene expression in skeletal muscle reserve cells. J Cell Sci 200I, I I 4:303-3 I0.

70. Mourkioti F, Rosenthal N: IGF-I, inflammation and stem cells: interactions during muscle regeneration. Trends Immunol 2005, 26:535-542.

71. Musaro A, McCullagh K, Paul A, Houghton L, Dobrowolny G, Molinaro M, Barton ER, Sweeney HL, Rosenthal N: Localized Igf-I transgene expression sustains hypertrophy and regeneration in senescent skeletal muscle. Nat Genet 200I, 27:195-200.

72. Hill M, Goldspink G: Expression and splicing of the insulin-like growth factor gene in rodent muscle is associated with muscle satellite (stem) cell activation following local tissue damage. J Physiol 2003, 549:409-4I8.
73. Hill M, Wernig A, Goldspink G: Muscle satellite (stem) cell activation during local tissue injury and repair. J Anat 2003, 203:89-99.

74. Bodine SC, Stitt TN, Gonzalez M, Kline WO, Stover GL, Bauerlein R, Zlotchenko E, Scrimgeour A, Lawrence JC, Glass DJ, Yancopoulos GD: Akt/mTOR pathway is a crucial regulator of skeletal muscle hypertrophy and can prevent muscle atrophy in vivo. Nat Cell Biol 200I, 3:1014-1019.

75. Rommel C, Bodine SC, Clarke BA, Rossman R, Nunez L, Stitt TN Yancopoulos GD, Glass DJ: Mediation of IGF-I-induced skeletal myotube hypertrophy by PI(3)K/Akt/mTOR and PI(3)K/Akt/ GSK3 pathways. Nature Cell Biol 200I, 3:1009-1013.

76. Machida S, Booth FW: Insulin-like growth factor I and muscle growth: implication for satellite cell proliferation. Proc Nut Soc 2004, 63:337-340.

77. Shavlakadze T, Winn N, Rosenthal N, Grounds MD: Reconciling data from transgenic mice that overexpress IGF-I specifically in skeletal muscle. Growth Horm IGF Res 2005, I 5:4- | 8 .

78. Parrizas $M$, LeRoith $D$ : Insulin-like growth factor-I inhibition of apoptosis is associated with increased expression of the bclxL gene product. Endocrinology 1997, 138: I355-1358.

79. Yin D, Tamaki N, Parent AD, Zhang JH: Insulin-like growth factorI decreased etoposide-induced apoptosis in glioma cells by increasing bcl-2 expression and decreasing CPP32 activity. Neurol Res 2005, 27:27-35.

80. Morgan DO: Cyclin-dependent kinases: engines, clocks, and microprocessors. Ann Revi Cell Dev Biol 1997, 13:26|-291.

8I. Murray AW: Recycling the cell cycle: cyclins revisited. Cell 2004, I I 6:221-234

82. Coqueret $\mathrm{O}$ : Linking cyclins to transcriptional control. Gene 2002, 299:35-55.

83. Ortega S, Malumbres M, Barbacid M: Cyclin D-dependent kinases, INK4 inhibitors and cancer. Biochim Biophys Acta 2002, 1602:73-87.

84. Boonstra J: Progression through the GI-phase of the on-going cell cycle. J Cell Biochem 2003, 90:244-252.

85. Pines J: Cyclin-dependent kinase inhibitors: the age of crystals. Biochim Biophys Acta 1997, I332(I):M39-M42.

86. Matushansky I, Radparvar F, Skoultchi Al: Manipulating the onset of cell cycle withdrawal in differentiated erythroid cells with cyclin-dependent kinases and inhibitors. Blood 2000, 96:2755-2764.

87. Kitzmann M, Fernandez A: Crosstalk between cell cycle regulators and the myogenic factor MyoD in skeletal myoblasts. Cell Mol Life Sci 200I, 58:57I-579.

88. Gartel AL, Radhakrishnan SK: Lost in transcription: p2I repression, mechanisms, and consequences. Cancer Res 2005 , 65:3980-3985.

89. Bunz F, Dutriaux A, Lengauer C, Waldman T, Zhou S, Brown JP, Sedivy JM, Kinzler KW, Vogelstein B: Requirement for p53 and p2I to sustain G2 arrest after DNA damage. Science 1998, 282: $|497-| 50 \mid$

90. Rigberg DA, Blinman TA, Kim FS, Cole MA, McFadden DW: Antisense blockade of $\mathrm{p} 2 \mathrm{I} / \mathrm{W} A F \mathrm{I}$ decreases radiation-induced G2 arrest in esophageal squamous cell carcinoma. J Surg Res 1999, 81:6-10.

91. De Siervi A, Marinissen M, Diggs J, Wang XF, Pages G, Senderowicz A: Transcriptional activation of $\mathrm{p} 2 \mathrm{I}$ (wafl/cip I) by alkylphospholipids: role of the mitogen-activated protein kinase pathway in the transactivation of the human $\mathrm{p} 2 \mathrm{I}$ (wafl/cipl) promoter by SpI. Cancer Res 2004, 64:743-750.

92. Shannan B, Seifert M, Boothman DA, Tilgen W, Reichrath J: Clusterin and DNA repair: a new function in cancer for a key player in apoptosis and cell cycle control. J Mol Histol 2006, 37:183-188.

93. Scaltriti M, Bettuzzi S, Sharrard RM, Caporali A, Caccamo AE, Maitland NJ: Clusterin overexpression in both malignant and nonmalignant prostate epithelial cells induces cell cycle arrest and apoptosis. Br J Cancer 2004, 9 1: 1842-1850.

94. Scaltriti M, Santamaria A, Paciucci R, Bettuzzi S: Intracellular clusterin induces G2-M phase arrest and cell death in PC-3 prostate cancer cells. Cancer Res 2004, 64:6I74-6I82.

95. Russell L, Forsdyke DR: A human putative lymphocyte G0/G I switch gene containing a CpG-rich island encodes a small basic protein with the potential to be phosphorylated. DNA Cell Biol 199I, 10:58I-59I. 
96. Zandbergen F, Mandard S, Escher P, Tan NS, Patsouris D, Jatkoe T, Rojas-Caro S, Madore S, Wahli W, Tafuri S, Muller M, Kersten S: The GO/GI switch gene 2 is a novel PPAR target gene. Biochem J 2005, 392:313-324.

97. Shi Y, Massague J: Mechanisms of TGF-beta signaling from cell membrane to the nucleus. Cell 2003, I I3:685-700.

98. Jasmer DP: Trichinella spiralis: altered expression of muscle proteins in trichinosis. Exp Parasitol 1990, 70:452-465.

99. Jasmer DP, Bohnet S, Prieur DJ: Trichinella spp.: differential expression of acid phosphatase and myofibrillar proteins in infected muscle cells. Exp Parasitol 1991, 72:321-33I.

100. Vassilatis DK, Despommier D, Misek DE, Polvere RI, Gold AM, Ploeg LH Van der: Analysis of a 43-kDa glycoprotein from the intracellular parasitic nematode Trichinella spiralis. I Biol Chem 1992, 267:18459-18465.

101. Carlson MR, Bryant SV, Gardiner DM: Expression of Msx-2 during development, regeneration, and wound healing in axolot limbs. J Exp Zool 1998, 282:7। 5-723.

102. Koshiba K, Kuroiwa A, Yamamoto H, Tamura K, Ide H: Expression of Msx genes in regenerating and developing limbs of axolotl. J Exp Zool 1998, 282:703-7।4.

103. Odelberg SJ, Kollhoff A, Keating MT: Dedifferentiation of mammalian myotubes induced by msxl. Cell 2000, 103:1099-1109.

104. Thompson-Jaeger S, Raghow R: Exogenous expression of Msx I renders myoblasts refractory to differentiation into myotubes and elicits enhanced biosynthesis of four unique mRNAs. Mol Cell Biochem 2000, 208:63-69.

105. Grounds MD, White JD, Rosenthal N, Bogoyevitch MA: The role of stem cells in skeletal and cardiac muscle repair. J Histochem Cytochem 2002, 50(5):589-610.

106. Hay ED: Microscopic observations of muscle dedifferentiation in regenerating Amplystoma limbs. Dev Biol 1959, I:555-585.

107. Hay ED, Fischman DA: Origin of the blastema in regenerating limbs of the newt Triturus viridescens. Dev Biol 1961, 3:26-59.

108. McGann CJ, Odelberg SJ, Keating MT: Mammalian myotube dedifferentiation induced by newt regeneration extract. Proc Natl Acad Sci USA 200I, 98:13699-13704.

109. Goldring K, Partridge T, Watt D: Muscle stem cells. J Pathol 2002, 197:457-467.

1 10. Watt $D$ J, Jones GE, Goldring K: The involvement of galectin-I in skeletal muscle determination, differentiation and regeneration. Glycoconj J 2004, 19:6I5-619.

II I. Chan J, O'Donoghue K, Gavina M, Torrente Y, Kennea N, Mehmet H, Stewart H, Watt DJ, Morgan JE, Fisk NM: Galectin-I induces skeletal muscle differentiation in human fetal mesenchymal stem cells and increases muscle regeneration. Stem Cells 2006, 24:|879-|89|.

112. Ferrari G, Cusella-De Angelis G, Coletta M, Paolucci E, Stornaiuolo $A$, Cossu G, Mavilio F: Muscle regeneration by bone marrowderived myogenic progenitors. Science 1998, 279:1528-1530.

113. Bittner RE, Schofer C, Weipoltshammer K, Ivanova S, Streubel B, Hauser $E$, Freilinger $M$, Hoger $H$, Elbe-Burger A, Wachtler $F$ : Recruitment of bone-marrow-derived cells by skeletal and cardiac muscle in adult dystrophic mdx mice. Anat Embryol 1999, 199:391-396.

114. Jankowski RJ, Deasy BM, Cao B, Gates C, Huard J: The role of CD34 expression and cellular fusion in the regeneration capacity of myogenic progenitor cells. J Cell Sci 2002, I 1 5:436|-4374.

II5. LaBarge MA, Blau HM: Biological progression from adult bone marrow to mononucleate muscle stem cell to multinucleate muscle fiber in response to injury. Cell 2002, I I I:589-60 I.

1 16. Qu-Petersen Z, Deasy B, Jankowski R, Ikezawa M, Cummins J, Pruchnic R, Mytinger J, Cao B, Gates C, Wernig A, Huard J: Identification of a novel population of muscle stem cells in mice: potential for muscle regeneration. J Cell Biol 2002, I 57:85I-864.

117. Seale P, Sabourin LA, Girgis-Gabardo A, Mansouri A, Gruss P, Rudnicki MA: Pax7 is required for the specification of myogenic satellite cells. Cell 2000, 102:777-786.

I 18. Steward GL: Pathophysiology of the muscle phase. In Trichinella and Trichinosis Edited by: Campbell WC. New York: Plenum Press; 1983:241-264.

119. Despommier DD, Gold AM, Buck SW, Capo V, Silberstein D: Trichinella spiralis: secreted antigen of the infective LI larva localizes to the cytoplasm and nucleoplasm of infected host cells. Exp Parasitol 1990, 71:27-38.
120. Lee DL, Ko RC, Yi XY, Yeung MH: Trichinella spiralis: antigenic epitopes from the stichocytes detected in the hypertrophic nuclei and cytoplasm of the parasitized muscle fibre (nurse cell) of the host. Parasitology 1991, 102:1 17-123.

121. Yao C, Bohnet S, Jasmer DP: Host nuclear abnormalities and depletion of nuclear antigens induced in Trichinella spiralisinfected muscle cells by the anthelmintic mebendazole. Mol Biochem Parasitol 1998, 96:1-13.

122. Yao C, Jasmer DP: Nuclear antigens in Trichinella spiralis infected muscle cells: nuclear extraction, compartmentalization and complex formation. Mol Biochem Parasitol 1998, 92:207-218.

123. Yao C, Jasmer DP: Trichinella spiralis-infected muscle cells: abundant RNA polymerase II in nuclear speckle domains colocalizes with nuclear antigens. Infect Immun 200I, 69:4065-407I.

124. Mak CH, Ko RC: DNA-binding activity in the excretory-secretory products of Trichinella pseudospiralis (Nematoda: Trichinelloidea). Parasitology 200 I, I 23:30 I-308.

125. Nagano I, Wu Z, Nakada T, Boonmars T, Takahashi Y: Molecular cloning and characterization of a serine proteinase gene of Trichinella spiralis. J Parasitol 2003, 89:92-98.

126. Nagano I, Wu Z, Nakada T, Matsuo A, Takahashi Y: Molecular cloning and characterization of a serine proteinase inhibitor from Trichinella spiralis. Parasitology 200।, I 23:77-83.

127. Nagano I, Wu Z, Takahashi Y: Molecular cloning and characterization of an Rcd I-like protein in excretory-secretory products of Trichinella pseudospiralis. Parasitology 2006, I 33:785-792

128. Tan TH, Edgerton SA, Kumari R, McAlister MS, Roe SM, Nagl S, Pearl LH, Selkirk ME, Bianco AE, Totty NF, Engwerda C, Gray CA, Meyer $D$ ]: Macrophage migration inhibitory factor of the parasitic nematode Trichinella spiralis. Biochim J 200I, 357:373-383.

129. Wu Z, Boonmars T, Nagano I, Nakada T, Takahashi Y: Molecular expression and characterization of a homologue of host cytokine macrophage migration inhibitory factor from Trichinella spp. J Parasitol 2003, 89:507-5 I5.

Publish with Bio Med Central and every scientist can read your work free of charge

"BioMed Central will be the most significant development for disseminating the results of biomedical research in our lifetime. "

Sir Paul Nurse, Cancer Research UK

Your research papers will be:

- available free of charge to the entire biomedical community

- peer reviewed and published immediately upon acceptance

- cited in PubMed and archived on PubMed Central

- yours - you keep the copyright
Biomedcentral 